\title{
PENGARUH PEMBERIAN KOMPOS TABLET DIPERKAYA MINERAL DAN Trichoderma sp. TERHADAP PRODUKTIVITAS DAN KANDUNGAN VITAMIN C BAWANG MERAH (Allium ascalonicum)
}

\author{
Zakiyuddin Ahmad, Chintya Ramadhani, Chintia Damayani Parangin Angin, dan \\ Eny Fuskhah \\ Departemen Pertanian, Fakultas Peternakan dan Pertanian, Universitas Diponegoro \\ Email: zakiyuddina2@gmail.com
}

\begin{abstract}
ABSTRAK
Penelitian ini untuk mengetahui hasil produksi tanaman bawang merah dan kandungan vitamin $\mathrm{C}$ umbi melalui perlakuan pemberian pupuk kompos diperkaya mineral dan Trichoderma sp. Penelitian disusun menggunakan rancangan acak lengkap monofaktor 6 perlakuan dan 4 ulangan dengan perlakuan tanpa pemberian pupuk, pupuk NPK mutiara $250 \mathrm{~kg} / \mathrm{ha}$, kompos tablet $5 \mathrm{ton} / \mathrm{ha}$, kompos tablet 10 ton/ha, kompos tablet 15 ton/ha, dan kompos tablet 20 ton/ha. Parameter yang diamati adalah, jumlah umbi, diameter umbi, berat kering umbi, berat kandungan vitamin $\mathrm{C}$ umbi. Data pengamatan dianalisis dengan ANOVA dilanjutkan uji DMRT. Hasil penelitian menunjukan perlakuan pemberian pupuk kompos tablet diperkaya mineral dan Trichoderma $s p$. tidak berpengaruh terhadap pertumbuhan tinggi tanaman, jumlah daun, dan diameter umbi bawang merah. Namun pemberian pupuk kompos tablet diperkaya mineral dan Trichoderma sp. pada dosis kompos tablet 20 ton/ha berpengaruh terhadap jumlah umbi, bahan kering tajuk, dan bahan kering umbi.

Kata Kunci-bawang merah; kompos; produksi; vitamin C
\end{abstract}

\section{PENDAHULUAN}

Indonesia merupakan negara dengan potensi pertanian salah satunya bawang merah. Produksi bawang merah tahun 2016 sebesar 1.446 .860 ton. Dibandingkan tahun 2015, produksi mencapai sebesar 1.229.184 ton. Produktivitas lahan panen bawang merah menurun yaitu tahun 2015 produktivitas mencapai 10,06 ton/ha dan tahun 2016 produktivitas lahan mencapai 9,67 ton/ha (Badan Pusat Statistik, 2017).

Faktor yang menyebabkan penurunan produktivitas lahan panen yaitu degradasi lahan budidaya. Degradasi lahan disebabkan oleh penggunaan bahan kimia anorganik yang dapat merusak tanah dan membunuh musuh alami hama. Upaya mengatasi permasalahan degradasi lahan, serangan penyakit, dan optimalisasi produktivitas bawang merah antara lain dengan perbaikan lahan. Perbaikan lahan dapat dilakukan dengan penambahan bahan organik, mineral pembenah tanah, dan mengoptimalkan fungsi agensi hayati. Pupuk organik dapat menyediakan unsur hara yang lengkap dan memperbaiki sifat fisik, kimia dan biologi tanah (Latarang dan Syakur, 2006).

Bahan yang dapat digunakan sebagai pembuatan pupuk organik adalah daun trembesi. Daun trembesi dapat digunakan sebagai pupuk kompos karena kandungan unsur hara makro $\mathrm{N}$ yang tinggi. Kandungan nitrogen daun trembesi sebesar 6.52\% (Fauziyah et al., 2017). Penggunaan daun trembesi sebagai pupuk kompos masih sedikit, sedangkan potensinya sangatlah tinggi, khususnya di sepanjang jalan pantura. Tanaman trembesi (Samanea saman) dapat tumbuh di daerah tropis dengan suhu $20^{\circ} \mathrm{C}$ $38{ }^{\circ} \mathrm{C}$, curah hujan $600-3000 \mathrm{~mm} /$ tahun, dan ketinggian tempat $0-300 \mathrm{mdpl}$. Periode pemotongan daun trembesi dapat dilakukan 2 tahun sekali. Pupuk organik dapat diperkaya dengan mineral alami, yaitu fosfat alam.

Fosfat alam merupakan sumber fosfor alami untuk pertumbuhan tanaman. Fosfor dibutuhkan tanaman untuk proses fotosintesis dan pembentukan energi. Batuan fosfat alam memiliki kandungan fosfor tinggi. Kandungan fosfor $\left(\mathrm{P}_{2} \mathrm{O}_{5}\right)$ pada batuan fosfat sebanyak 20-40\% (Maryanto dan Ismangil, 2010). Mineral lin yang ditambahkan pada pupuk organik adalah zeolit. Mineral zeolit dapat digunakan dalam memperbaiki lahan yang mengalami degradasi karena mampu memperbaiki sifat fisik dan kimia tanah. Zeolit mempunyai kapasitas penyerapan hara terutama $\mathrm{K}$ dan $\mathrm{NH}_{4}$ yang tinggi, sehingga kemampuan tanah dalam mengikat unsur-unsur tersebut dapat meningkat (Suwardi, 2009). Mineral alam selain sebagai pembenah tanah juga dapat digunakan sebagai pembawa agensi antagonis seperti Trichoderma sp. 
Cendawan Trichoderma sp. merupakan jamur antagonis yang mampu mengendalikan organisme pengganggu tanaman (OPT) melalui zat-zat metabolisme yang dihasilkan serta meningkatkan kesuburan tanah melalui dekomposisi bahan organik (Sepwanti et al., 2016). Penambahan agensi antagonis Trichoderma sp. dapat memperkaya kandungan dari pupuk organik. Penelitian ini dilakukan untuk mengetahui pengaruh pupuk tablet kompos yang diperkaya mineral dan Trichoderma sp. terhadap pertumbuhan dan produksi bawang merah.

\section{METODOLOGI PENELITIAN}

\section{A. Waktu dan Tempat}

Penelitian akan dilakukan di Greenhouse, dan Laboratorium Ekologi dan Produksi Tanaman, Fakultas Peternakan dan Pertanian, Universitas Diponegoro, Semarang dari bulan Maret sampai dengan Juni 2019.

\section{B. Bahan dan Alat}

Alat-alat yang digunakan dalam penelitian ini adalah polybag, sekop, cangkul, timbangan analitik, destilator, spektrofotometer, jangka, dan kamera. Bahan penelitian yang digunakan yaitu daun trembesi, batuan fosfat, zeolit, isolat Trichoderma sp., media tanam berupa tanah latosol, dan benih bawang

\section{Prosedur Penelitian}

Rancangan penelitian ini yaitu Rancangan Acak Lengkap (RAL) monofaktor 6 perlakuan dengan 4 ulangan. Faktor tersebut adalah pemberian dosis terdiri atas kontrol/tanpa pemberian pupuk (P0), Pupuk NPK mutiara $250 \mathrm{~kg} / \mathrm{ha}(\mathrm{P} 1)$, kompos tablet 5 ton/ha (P2), kompos tablet 10 ton/ha (P3), kompos tablet 15 ton/ha (P4), kompos tablet 20 ton/ha (P5). Data yang diperoleh dianalisis menggunakan Analysis of Variant (ANOVA) dan dilanjutkan dengan uji DMRT.

Daun trembesi dikomposkan selama 2 bulan. Kompos daun trembesi dicampurkan dengan batuan fosfat, zeolit, dan Trichoderma sp. dengan perbandingan 4:2:2:1. Pupuk dicetak tablet dan dikeringkan. Pupuk yang sudah kering diaplikasikan ke tanaman. Aplikasi ke tanaman pada 2 minggu setelah tanam (MST).

\section{Parameter Pengamatan}

Parameter yang diamati adalah jumlah umbi, diameter umbi, berat kering umbi, dan berat tajuk tanaman bawang merah, serta kandungan vitamin $\mathrm{C}$.

a. Jumlah umbi dihitung secara manual yaitu dilakukan pengukuran setelah panen pada setiap unit penelitian.

b. Diameter umbi diukur secara manual yaitu setelah panen selama 60 hari, setiap umbi pada masing-masing unit penelitian diukur menggunakan jangka.

c. Berat kering umbi diukur menggunakan oven selama 24 jam kemudian ditimbang menggunakan timbangan digital

d. Berat tajuk tanaman bawang merah diukur menggunakan timbangan digital pada setiap unit penelitian.

e. Uji vitamin $\mathrm{C}$ dilakukan dengan menimbang $2 \mathrm{~g}$ sampel yang telah dihaluskan. Larutan sampel dalam $50 \mathrm{~mL}$ akuades, kemudian menanda batas larutan dalam labu takar $250 \mathrm{~mL}$. setelah itu larutan diencerkan hingga 200 kali, kemudian absorbansi diukur pada panjang gelombang 190 $380 \mathrm{~nm}$.

\section{HASIL DAN PEMBAHASAN}

\section{Jumlah Umbi Bawang Merah}

Hasil uji anova (Tabel 1) menunjukkan bahwa jumlah umbi yang terbaik adalah pada perlakuan pupuk kompos tablet dengan dosis 20 ton/ha. Jumlah umbi pada perlakuan kompos tablet 20 ton/ha berbeda nyata dengan perlakuan kontrol dan NPK rekomendasi. Hal ini dikarenakan jumlah umbi dipengaruhi oleh ketersediaan unsur hara fosfor dan kalium pada tanah serta peningkatan dosis Trichoderma sp.. Hal ini sesuai dengan pendapat Sumarni et al. (2012) yang menyatakan bahwa 
pembentukan umbi dipengaruhi oleh ketersediaan hara fosfor dan kalium. Hal ini juga didukung pendapat Sihombing et al. (2013) yang menyatakan bahwa peningkatan dosis Trichoderma sp. meningkatkan jumlah siung bawang merah. Hasil uji parameter diameter umbi bawang merah diberi kompos tablet 20 ton/ha menunjukan perbedaan nyata dengan tanpa diberi pupuk, tetapi menunjukan hasil yang setara dengan perlakuan NPK rekomendasi.

Tabel 1. Jumlah Umbi dan Diamater Bawang Merah

\begin{tabular}{cc}
\hline Perlakuan & Jumlah umbi (buah) \\
\hline P0 & $7.5 \mathrm{~b}$ \\
P1 & $7.5 \mathrm{~b}$ \\
P2 & $9 \mathrm{~b}$ \\
P3 & $8.33 \mathrm{~b}$ \\
P4 & $7.75 \mathrm{~b}$ \\
P5 & $11.75 \mathrm{a}$
\end{tabular}

*superskrip yang berbeda pada kolom atau baris rata-rata menunjukkan berbeda nyata $(\mathrm{p}<0,05)$.

Jumlah umbi bawang merah pada perlakuan kompos tablet 20 ton/ha menunjukan jumlah paling tinggi dan telah sesuai dengan potensi dari bawang merah varietas Bima. Menurut Azmi et al. (2011) yang menyatakan bahwa jumlah umbi bawang merah varietas Bima mencapai 11.73. Potensi maksimum jumlah umbi bawang merah adalah 7 - 12 umbi per tanaman. Menurut Koswara (2007) yang menyatakan bahwa bawang merah varietas Bima tumbuh optimum pada lahan dengan sulfat asam.

\section{Diameter Umbi Bawang Merah}

Hasil uji anova (Tabel 2) menunjukkan bahwa diameter umbi bawang merah yang terbaik adalah pada perlakuan pupuk kompos tablet dengan dosis 20 ton/ha. Hasil uji parameter diameter umbi bawang merah diberi kompos tablet 20 ton/ha menunjukan perbedaan nyata dengan tanpa diberi pupuk, tetapi menunjukan hasil yang setara dengan perlakuan NPK rekomendasi. Hal ini dikarenakan pembesaran umbi bawang merah dipengaruhi oleh ketersediaan unsur hara fosfor dan kalium pada tanah. Hal ini sesuai dengan pendapat Sumarni et al. (2010) yang menyatakan bahwa pengisian umbi bawang merah dapat dipengaruhi oleh unsur hara fosfor dan kalium. Unsur kalium diperoleh dari input silika yang dicampurkan pada kompos. Menurut Prasetiya et al. (2015) yang menyatakan bahwa unsur kalium berperan dalam pengaktifan enzim yang dubtuhkan untuk membentuk pati dan protein.

\begin{tabular}{cc}
\multicolumn{2}{c}{ Tabel 2. Diamater Umbi Bawang Merah } \\
\hline Perlakuan & Diameter umbi $(\mathrm{cm})$ \\
\hline P0 1 & $1.2 \mathrm{a}$ \\
P1 & $1.35 \mathrm{~b}$ \\
P2 3 & $1.2 \mathrm{a}$ \\
P4 & $1.08 \mathrm{a}$ \\
P5 & $1.23 \mathrm{a}$ \\
* 3 superskrip yang berbeda pada kolom atau baris rata-rata menunjukkan \\
berbeda nyata $(\mathrm{p}<0,05)$.
\end{tabular}

Selain faktor kesediaan unsur hara, ukuran diameter umbi juga dipengaruhi oleh faktor genetik. Menurut Azmi et al. (2011) yang menyatakan bahwa fenotipik tanaman dipengaruhi oleh dua unsur yaitu genetik dan kondisi lingkungan. Menurut Kartinaty et al. (2018) yang menyatakan bahwa diameter umbi bawang merah varietas Bima yang ditanam di Kalimantan Barat adalah $9.55 \mathrm{~mm}$ atau setara dengan $0.96 \mathrm{~cm}$. Hasil penelitian Rusdi dan Asaad (2016) yang menyatakan bahwa diameter umbi bawang merah varietas Bima yang ditanma di Kolaka Timur, Sulawesi Tenggara adalah 3,39 $\mathrm{cm}$. Hal ini dipengaruhi oleh lingkungan dari lokasi budidaya. Menurut Tambak et al. (2013) yang menyatakan bahwa respon setiap varietas pada kondisi lingkungan yang meliputi curah hujan, 
intensitas sinar matahari dan kelembaban udara berbeda-beda. Kondisi lingkungan yang tidak optimal dapat menghambat laju pertumbuhan dan produksi tanaman akibat dari fitohormon pada tanaman tidak dihasilkan secara optimal.

\section{Berat Kering Tajuk dan Umbi Bawang Merah}

Hasil uji anova (Tabel 3) menunjukkan bahwa bahan kering tajuk dan umbi bawang merah terbaik adalah pada perlakuan pupuk kompos tablet dengan dosis 20 ton/ha. Berat kering tajuk pada perlakuan kompos tablet 20 ton//ha mampu meningkatkan bahan kering tajuk tanaman hingga $40 \%$ dibandingkan dengan menggunakan pupuk anorganik/ NPK rekomendasi $(\mathrm{P}<0,05)$.

Tabel 3. Bahan Kering Tajuk dan Umbi Bawang Merah

\begin{tabular}{ccc}
\hline Perlakuan & Berat kering tajuk $(\mathrm{g})$ & Berat kering umbi $(\mathrm{g})$ \\
\hline P0 & $5.50 \mathrm{~b}$ & $37.5 \mathrm{c}$ \\
P1 & $6.01 \mathrm{~b}$ & $41.82 \mathrm{c}$ \\
P2 & $6.29 \mathrm{~b}$ & $35.1 \mathrm{c}$ \\
P3 & $6.70 \mathrm{~b}$ & $43.79 \mathrm{bc}$ \\
P4 & $6.93 \mathrm{~b}$ & $45.99 \mathrm{~b}$ \\
P5 & $7.61 \mathrm{a}$ & $57.91 \mathrm{a}$ \\
\hline
\end{tabular}

*superskrip yang berbeda pada kolom atau baris rata-rata menunjukkan berbeda nyata $(\mathrm{p}<0,05)$.

Kompos tablet mampu menyediakan unsur hara yang lengkap. Hal ini sesuai dengan pendapat Latarang dan Syakur (2006) yang menyatakan bahwa pupuk organik memiliki kandungan hara yang lengkap. Penambahan biomassa oleh tajuk hubungannya dengan ketersediaan unsur hara nitrogen yang berfungsi untuk pembentukan klorofil. Klorofil berperan dalam upaya pembentukan makanan melalui fotosintesis. Hal ini sesuai dengan pendapat Napitulu dan Winarto (2010) yang menyatakan bahwa input pupuk $\mathrm{N}$ dan $\mathrm{K}$ penting untuk meningkatkan produktivitas umbi bawang merah. Hasil uji parameter berat kering umbi bawang merah Pemberian kompos tablet 20 ton/ha mampu meningkatkan bahan kering umbi hingga 52,5\% daripada menggunakan pupuk anorganik/ NPK rekomendasi. Hal ini sesuai dengan pendapat Latarang dan Syakur (2006) yang menyatakan bahwa pupuk organik memiliki kandungan hara yang lengkap.

\section{Kadar Vitamin C Umbi Bawang Merah}

Hasil kadar vitamin $\mathrm{C}$ umbi bawang merah yang terbaik adalah pada perlakuan $\mathrm{P} 0$ atau kontrol (Tabel 4). Kadar vitamin C umbi bawang merah pada perlakuan kontrol (tanpa perlakuan) adalah $26.801 \mathrm{mg} / \mathrm{L}$, sedangkan nilai paling rendah adalah perlakuan yang diaplikasikan dengan pupuk anorganik, dengan nilai $2,3 \mathrm{mg} / \mathrm{L}$. Menurut Nurman et al., (2017) yang menyatakan bahwa kadar vitamin C umbi bawang merah berkisar pada 2,00 mg/100 g. Vitamin C merupakan salah satu jenis antioksidan. Menurut Nurjannah et al. (2018) yang menyatakan bahwa vitamin C merupakan vitamin larut air dan bekerja sebagai koenzim dan reduktor serta antioksidan. Lingkungan tumbuh yang tidak optimum dapat meningkatkan kadar vitamin C pada tanaman. Menurut Fajar et al. (2018), yang menyatakan bahwa kadar vitamin $\mathrm{C}$ akan meningkat pada kondisi tercekam panas. Sehingga, adanya cekaman dapat meningkatkan kadar vitamin $\mathrm{C}$ pada tanaman, termasuk cekaman unsur.

Tabel 4. Kadar Vitamin C Umbi Bawang Merah

\begin{tabular}{cc}
\hline Perlakuan & Kadar vitamin $\mathrm{C}(\mathrm{mg} / \mathrm{L})$ \\
\hline P0 & 26.801 \\
P1 & 2.310 \\
P2 & 23.928 \\
P3 & 23.596 \\
P4 & 21.041 \\
P5 & 10.455 \\
\hline
\end{tabular}




\section{KESIMPULAN}

Pemberian pupuk kompos tablet yang diperkaya mineral dan cendawan Trichoderma $s p$. dengan dosis 20 ton/ha dapat berpengaruh nyata terhadap produksi dan pertumbuhan bawang merah dibandingkan dengan kontrol dan pemberian pupuk NPK. Pemberian kompos tablet 20 ton/ha mampu memberikan hasil terbaik terhadap produksi dibandingkan dengan perlakuan kontrol dan NPK rekomendasi, serta mampu menyamai pada parameter pertumbuhan tanaman dibandingkan dengan NPK rekomendasi.

\section{DAFTAR PUSTAKA}

Azmi, C., I.M. Hidayat dan G. Wiguna. 2011. Pengaruh Varietas dan Ukuran Umbi terhadap Produktivitas Bawang Merah. J. Hort. 21(3): 206-213.

Fajri, R. Rahmatu dan N. Alam. 2018. Kadar Klorofil Dan Vitamin C Daun Kelor (Moringa oleifera Lam) Dari Berbagai Ketinggian Tempat Tumbuh. J. Agroekotekbis, 6(2): 152-158.

Fauziyah, F., Winarsih dan H. Fitrihidajati. 2017. Pemanfaatan Sampah Daun Trembesi (Samanea saman) Dan Daun Angsana (Pterocarpus indicus) Sebagai Bahan Baku Kompos. J. LenteraBio. $6(3): 76-79$.

Juwanda, M., K. Khotimah dan M. Amin. 2016. Peningkatan Ketahanan Bawang Merah Terhadap Penyakit Layu Fusarium Melalui Induksi Ketahanan Dengan Asam Salisilat Secara Invitro. J. Agrin. 20 (1) : 15-28.

Koswara, E. 2007. Teknik Pengujian Daya Hasil Beberapa Varietas Bawang Merah di Lahan Pasang Surut Sumatera Selatan. Bul. Teknik Pertanian. 19(3): 281-286.

Kartinaty, T., Hartono dan Serom. 2018. Penampilan Pertumbuhan dan Produksi Lima Varietas Bawang Merah (Allium ascalonicum) di Kalimantan Barat. J. Buana Sains, 18(2): 103-108.

Latarang, B., dan A. Syakur. 2006. Pertumbuhan Dan Hasil Bawang Merah (Allium ascalonicum L.) Pada Berbagai Dosis Pupuk Kandang. J. Agroland. 13 (3) : 265 - 269.

Maryanto, J., dan Ismangil. 2010. Pengaruh Pupuk Hayati Dan Batuan Fosfat Alat Terhadap Ketersediaan Fosfor Dan Pertumbuhan Stroberi Pada Tanah Andisol. J. Hort. Indonesia. 1 (2) : 66-73.

Napitulu, D. dan L. Wianrto. 2010. Pengaruh Pemberian Pupuk N Dan K Terhadap Pertumbuhan Dan Produksi Bawang Merah. J. Hort. 20 (1) : 27 - 35.

Nurjannah. D., S.M. Sabang, dan Afdil. 2018. Analisis Kadar Vitamin C, Kalsium Dan Fosforus Pada Cabai Rawit (Capsicum frustescens L.) Hasil Pengawetan. J. Akademika Kimia. 7 (4): 185-188.

Nurman., E. Zuhry, dan I. R. Dini. Pemanfaatan ZPT Air Kelapa Dan POC Limbah Cair Tahu Untuk Pertumbuhan Dan Produksi Bawang Merah. J. Faperta. 4 (2): 1 - 15.

Prakoso, E.B., S. Wiyatingsih, dan H. Nirwanto. 2016. Uji Ketahanan Berbagai Kultivar Bawang Merah (Allium Ascalonicum) Terhadap Infeksi Penyakit Moler (Fusarium oxysporum f.sp.cepae). J. Plumula. 5 (1) : 10-20.

Prasetia, R., M. Utomo, Afandi dan I. S. Banuwa. 2010. Pengaruh sistem olah tanah dan pemupukan nitrogen jangka panjang terhadap air tersedia dan beberapa sifat fisik tanah pada pertanaman padi gogo (Oryza sativa L.) di lahan polinela Bandar Lampung. J. Agrotek Tropika. 6 (2) : 119 $-126$

Prasetiya, A., L. Mawarni dan J. Ginting. 2015. Respon Bawang Merah (Allium ascalonicum L.) Vareitas Medan pada Tanah Vulkanik dengan Pemberian Bahan Organik. J. Agroekoteknologi. 3(2): 476-482.

Rusdi dan M. Asaad. 2016. Uji Adaptasi Empat Varietas Bawang Merah di Kabupaten Kolakan Timur, Sulawesi Tenggara. J. Pengkajian dan Pengembangan Teknologi Pertanian. 19(3): 243252.

Sepwanti, C., M. Rahmawati, dan E. Kesumawati. 2016. Pengaruh Varietas Dan Dosis Kompos Yang Diperkaya Trichoderma Harzianum Terhadap Pertumbuhan Dan Hasil Tanaman Cabai Merah (Capsicum annuum L.). J. Kawista 1(1):68-74.

Sihombing, C., H. Setiado dan H. Hasyim. 2013. Tanggap Beberapa Varietas Bawang Merah (Allium ascalonicum L.) Terhadap pemberian Trichoderma sp. J. Online Agroekoteknologi. 1 (3): 385 395. 
Jurnal Teknologi Pertanian Andalas Vol. 24, No. 1, Maret 2020. ISSN 1410-1920, EISSN 2579-4019

Zakiyuddin Ahmad, Chintya Ramadhani, Chintia Damayani Parangin angin, dan Eny Fuskhah

Suwardi. 2009. Teknik Aplikasi Zeolit Di Bidang Pertanian Sebagai Bahan Pembenah Tanah. J. Zeolit Indonesia. 8 (1): 33-38.

Tambak, D.G.P., L.A.M. Siregar dan Rosmiyati. 2013. Respons Pertumbuhan dan Produksi Beberapa Varietas Bawang Merah (Allium ascalonicum L.) dengan Pemberian Kompos Limbah Kakao pada Tanah Inseptiso. J. Agroekoteknologi. 2(1): 95-102. 